\title{
Antijogo: considerações em torno de uma categoria da diferença
}

Anti-game: considerations around a difference category

Luiz Henrique de Toledo*

*Universidade Federal de São Carlos - São Carlos, SP, Brasil

kikeppgas@gmail.com

https://orcid.org/0000-0002-5354-5923 


\title{
Resumo
}

O artigo problematiza a categoria nativa de antijogo, circunscrita em princípio aos domínios esportivos, embora seja sabido que se está diante de uma daquelas metáforas que facilmente escapam da seara originária para se converter em noção geral do simbolismo acomodado em múltiplas práticas. Antijogo como má conduta, comumente tipificada como ação individual, está correlacionado à ideia de estabilidade normativa que ampara as relações e práticas esportivas, mas também pode remeter ao domínio da sociabilidade em contextos mais amplos em que aparece significando burla e contrafação. Neste artigo procuro não apenas rever criticamente a noção de antijogo como suposta antítese daquilo que ao longo do tempo se estabeleceu como substrato dos esportes, isto é, os jogos e passatempos desdobrados no interior dos Estados nacionais, tomando o futebol como exemplo, mas também enfrentar uma questão metodológica que assume o regime da diferença e não necessariamente o da identidade como fundamento das conceitualizações repostas em noções correntes que amparam algumas definições de jogo e, por simples inércia antagônica, as de antijogo.

Palavras-chave: antijogo; imitação; jogo; antropologia das práticas esportivas.

\begin{abstract}
The article problematizes the native category of anti-game, limited in principle to the sportive domains, although it is known that one is faced with one of those metaphors that easily escape from the original field to become a general notion of the symbolism. Anti-game as misconduct, commonly typified as individual action, is correlated with the idea of normative stability that supports sports relations and practices, but can also refer to the domain of sociability in broader contexts where it appears to imply mocking and counterfeiting. In this article, I try to critically review the notion of anti-game not only as a supposed antithesis of what it has established itself as the substrate of sports, that is, games and pastimes, taking football as an example, but thinking as a methodological strategy: the regime of difference and not necessarily that of identity as the basis of the conceptualizations that support some definitions of game and, by simple antagonistic, those of anti-game.
\end{abstract}

Keywords: anti-game; imitation; game; anthropology of sports practices. 
Antijogo (an.ti.jo.go) [ô] sm. 1. Esp. Prática de faltas desonestas ou de expedientes ilícitos, ou qualquer ação de desrespeito à ética esportiva, em competição, partida etc.:

"Foi uma demonstração do antijogo da França" (BBCBrasil.com) 2. A competição ou partida em que isso acontece 3. Fig. Qualquer prática ou ação abusiva, que desrespeite

à ética, à moralidade ou à legalidade.

Dicionário Aulete Digital ${ }^{1}$

\section{Introdução}

Este texto visa problematizar conceitualmente a categoria nativa de antijogo, circunscrita em princípio aos domínios esportivos, embora seja sabido que se está diante de uma daquelas metáforas que facilmente escapam da seara originária para se converter em noção geral arraigada ao simbolismo que se acomoda em múltiplas práticas. Antijogo expressando má conduta individual parece crescer à sombra da ideia de estabilidade normativa coletiva enfeixada nas relações e práticas esportivas, mas também presente num vasto domínio da sociabilidade e contextos muito mais amplos em que aparece como burla ou contrafação.

Traço aqui, então, o caminho dos argumentos. Primeiro, na parte denominada "Uma categoria da diferença", mostrarei em alguns tópicos desdobrados como antijogo pode deslocar, rasurar ou alargar alguns conceitos sociológicos de uso corrente, tais como sociedade, sociação, representação e, sobretudo, sociabilidade, em vez de simplesmente se contrapor valorativamente a esse repertório sociológico a partir de uma espécie de limbo ou liminaridade analítica. ${ }^{2}$ Diferença não se apresenta, é preciso que se afirme, como um conceito

1 Ver http://www.aulete.com.br/antijogo (acesso em 30/01/2019).

2 Os usos do prefixo "anti" aparecem em conceituações ou inspirações na antropologia em vários momentos e lembro aqui especificamente aqueles que se tornaram conhecidos dos estudos sobre futebol em contexto brasileiro e que são tributários das contribuições de Roberto DaMatta, autor para quem a burla, a imitação, o jeitinho como estratégias sociais e formas da ambiguidade consistem em chaves e categorias centrais de sua (socio)lógica à brasileira ou "para" brasileiros. Desdobramentos críticos mais sofisticados, mas sem baratear a força do modelo damattiano podem ser consultados em Geiser e Velho (2000). Cabe aqui somente destacar que o seu amálgama conceitual foi seguido de perto por outros destacados pesquisadores e pesquisadoras do panorama futebolístico. DaMatta trouxe para o centro de suas contribuições autores como Victor Turner, a quem se atribui na antropologia a noção de antiestrutura, no caso damattiano utilizada não apenas como avesso de estruturas mecanicistas ou naturalizadas $\rightarrow$ 
contraposto a esses ou a outras noções tais como identidade. Aqui assumo que diferença não tem peso conceitual, bem como não tipifica tal ou qual fenômeno e nesse sentido não é tomada em si mesma como propulsora analítica, mas decorre ou está presente ou ainda se abriga nos fenômenos; para os propósitos deste artigo, trata-se de um recurso heurístico. Nesse sentido mobilizo uma proposição ampla o suficiente sugerida por Tarde (2003, p. 70): "Existir é diferir, e, de certa forma, a diferença é a dimensão substancial das coisas, aquilo que ela tem de mais próprio e mais comum [...] para onde tudo caminha, mesmo a identidade." Essa ideia será retomada ao final do artigo.

Segundo, mobilizarei três exemplos breves em "Etnografando antijogos", para dar alguma concretude aos argumentos tratados mais abstratamente. Um primeiro caso vem de uma tese de doutorado que tive a oportunidade de arguir, sobre museus esportivos (Alfonsi, 2018), em que a autora traz uma perspicaz análise comparativa entre museus de futebol em alguns contextos reveladores de como este esporte foi tomado por metáforas de identidades nacionais. Aqui a dimensão da imitação aparece como fabulação histórica identitária e é encenada na produção museológica de relíquias. Centrarei num exemplo pontual em que a autora mobiliza em sua etnografia a manifestação daquilo que percebeu, tomada pela sensibilidade contemporânea, como um típico caso de antijogo. No segundo exemplo tratarei da "falsa" técnica corporal da mordida como recurso na ampliação do espaço e posicionamento na disputa da bola numa partida, técnica reconhecida como "atitude imoral", animalesca, condenável esportivamente, numa clara expressão de antijogo pessoalizado protagonizado pelo jogador Luis Suárez da seleção uruguaia, utilizada num jogo de Copa do Mundo no ano de 2014.

Terceiro e por último, mobilizo o conhecidíssimo, sobretudo para aqueles que são tocados pelo campo futebolístico, caso paradigmático de falsificação

$\rightarrow$ a produzir situações e condições de liminaridade, numa chave por vezes binarista, mas também amparando mecanismos da hierarquia de inspiração dumontiana que ativaria contextualmente uma espécie de pêndulo entre duas figurações complementares (holismo e individualismo tomados como "dilema" socioexistencial). Nessa tradição antropológica de estudos sobre esportes outro termo recorrente seria o de anti-herói, explorado, por exemplo, por Simoni Guedes (2000) ao tratar de casos singulares de jogadores de renome que ao enfrentarem fracassos esportivos reatualizariam tais mecanismos pendulares entre biografia e performance, entre origens sociais humildes e riqueza excessiva amealhada no futebol, reatualizando dilemas estruturais e reafirmando antiestruturas presentes na sociedade. 
de decoro esportivo protagonizado por Maradona na expressão la mano de Dios, ato solitário que produziu enorme repercussão coletiva, mais que desdobrado em implicações éticas e políticas.

Advirto ainda para o fato de que há toda uma literatura filosófica, ensaística, psicológica, socioantropológica e historiográfica em torno da noção de jogo e suas correlações com as práticas esportivas. Por razões de espaço e delimitação de um argumento será impossível dar conta aqui de tantas conceituações espalhadas numa ampla bibliografia em constante movimento. ${ }^{3}$

Longe, obviamente, de reivindicar para a categoria antijogo um lugar entre aquelas que ostentariam a universalidade das categorias do espírito humano, no sentido apriorístico que conformaria a gênese das categorias sociais proposta pela escola sociológica francesa, sua contraface, jogo, assume, por chaves diferenciadas, um lugar epistemológico crucial numa bibliografia específica considerada basilar em que os nomes de Huizinga (1993), ${ }^{4}$ Callois (1994) e Elias (1978) ${ }^{6}$ aparecem reiteradamente.

3 Entretanto, para aqueles que se comprazem com os jogos de definições, sugiro recorrer aos balanços bibliográficos. Eu mesmo e há tempos propus um, parcial e cada vez mais datado, que pode ser consultado em Toledo (2001).

4 Afinal, "seria mais ou menos óbvio, mas também um pouco fácil, considerar 'jogo' toda e qualquer atividade humana. Aqueles que preferirem contentar-se com uma conclusão metafísica deste gênero farão melhor não lerem este livro. Não vejo, todavia, razão alguma para abandonar a noção de jogo como um fator distinto e fundamental, presente em tudo o que acontece no mundo. Já há muitos anos que vem crescendo em mim a convicção de que é no jogo e pelo jogo que a civilização surge e se desenvolve" (Huizinga, 1993, prefácio).

5 Callois (1994) propõe níveis tipológicos gerais (jogos de competição, jogos de azar, jogos de representação e jogos de vertigem) que acomodariam das manifestações da subjetividade, o sair de si mesmo como experimentação de um jogo das sensações, às atividades conscientes manifestas nas formas competitivas que assumem dimensões ditas mais sociológicas da prática.

6 Alguns comentadores da teoria sociológica configuracional apontarão para essa centralidade que jogo assume para essa teoria, seleciono um em específico: “O jogo não é definido como um corpo de regras, mas como uma combinação móvel e específica de relações sociais reais [...] Assim, os grupos não são coisas: tampouco são estáticos, apenas reificados pela linguagem e em percepções nominalistas que inferem a substância do substantivo. Sem fazer uma exegese dos termos, é oportuno observar que não se trata de uma simples analogia, uma vez que não está escrito exatamente que esse movimento é 'como um jogo', mas que 'é' o jogo" e "[...] assume uma certa ambivalência por ser um instrumento analítico mas também uma noção realista [...] concebidos como 'tensões miméticas', [os jogos] reproduzem as relações efetivas dos homens entre si, sob formas simplificadas, depuradas, com vistas ao prazer e ao desempenho [...] o jogo se apresenta como uma lei geral do funcionamento social e se impõe, pois, como um imperativo do qual ninguém poderia fugir" (Garrigou, 1997, p. 78). 
Todavia, parto de um autor menos mobilizado dentro do campo dos estudos sobre esportes, Simmel (2006, p. 62, grifo meu), para quem jogo ativaria a natureza dialética entre matérias e conteúdos expressivos e suas formas estilizadas como expressões mais fugidias que a vida em sociedade encontra para estabelecer sua presença no tempo e espaço:

Essas formas, contudo, se tornam autônomas dos conteúdos e estímulos autônomos dentro do próprio jogo, ou melhor, como jogo. Caçar, conquistar, contrapor forças físicas e espirituais, competir, pôr-se à mercê do acaso e do capricho de poderes sobre os quais não se tem qualquer influência - tudo isso que antes aderia à vida em sua seriedade, agora se subtrai a seu fluxo, à sua matéria, desapega-se da vida. Autonomamente, escolhe ou cria os objetos nos quais irá se testar e representar-se em sua pureza. Isso confere ao jogo tanto sua alegria quanto seu significado simbólico, tornando-o diferente do puro divertimento.

Aqui, repito, tentarei apenas acomodar antijogo a uma expressão motivada por questões metodológicas, passando a estabelecê-la como uma categoria da diferença. De todo modo, creio ainda que se possa restringir e ao mesmo tempo generalizar dizendo que a categoria jogo está para os pesquisadores de esportes e fenômenos lúdicos assim como o conceito de cultura estaria para a antropologia, quer dizer, não se trata tão somente de buscar uma definição segura, sociológica ou etnográfica, inclusiva ou pragmática, mas de perceber até onde tais noções poderiam arregimentar novos objetos e recortes, demandas conceituais e explorar novos métodos de abordagem.

Saliento por último que jogo pode ser tomado menos a partir da imagem de um feixe de práticas e fenômenos históricos solidários entre $\mathrm{si}^{7}$ e passo a aderir à ideia de que perscrutar as condições de possibilidade de aparecimento do antijogo é perceber as correlações que suas formas de agenciamento impõem na vida de modo geral.

7 Não é raro esses enfeixamentos temporais definirem múltiplas experiências sob a rubrica de jogo, sobretudo em propostas que visam cobrir amplos espectros de práticas. Para uma perspectiva histórica que segue essa decisão metodológica ver, por exemplo, Vigarello e Holt (2005) ou mesmo Gay (2001, p. 436) ao contextualizar as formas sociais denominadas de esportes como mecanismo de canalização da agressão no contexto vitoriano: “[...] encontrar emprego pacífico para impulsos agressivos". 


\section{Uma categoria da diferença}

\section{Sociabilidade e jogos sociais}

Fixemo-nos numa definição de Simmel (2006, p. 80) para sociabilidade:

Toda sociabilidade é um símbolo da vida quando esta surge no fluxo de um jogo prazeroso e fácil. Porém, é justamente um símbolo da vida cuja imagem se modifica até o ponto em que a distância em relação à vida o exige. Da mesma maneira, para não se mostrar vazia e mentirosa, a arte mais livre, fantástica e distante da cópia de qualquer realidade se nutre de uma relação profunda e fiel com a realidade.

Há muitas implicações nesse parágrafo e poderíamos primeiramente considerar que o jogo entre "forma" e "conteúdo" compreenderia aqui a noção simmeliana de sociabilidade. Como forma, sociabilidade seria um tipo ideal puro de sociação baseada na convivialidade entre iguais ou tentativa de alcançar esse igualitarismo fugidio mediado por relações que estrategicamente deveriam abrir mão de parte da seriedade da vida (diga-se interesses divergentes alicerçados em estruturas sabidamente desiguais e fortemente monetarizadas, que juntam pessoas dessemelhantes para que essa paz civilizacional acordada se instaure).

Sociabilidade simmeliana é pensada em contextos específicos, as cidades europeias, e, sobretudo, contextos metropolitanos que sustentariam elaboradas ficções relacionais na medida em que se apresentam não somente como substratos físicos dos manejos da sociação, termo, aliás, que Simmel utiliza às expensas de "sociedade", mas também prefigurando uma totalidade como "categoria alegórica de sociedade" (Fortuna, 2011, p. 12), epistemologicamente alicerçada numa filosofia do dinheiro (Waizbort, 2013, p. 318). Há um timing ético e estético cujas expressões e manifestações da sociabilidade devem se nortear em relação aos vínculos com aquilo que o autor denomina de "realidade", sob o risco de ser desacreditada.

Historicamente marcada pelo fato do convívio de interesses divergentes (grupos, categorias, classes), presença do anonimato que encapsula os indivíduos em suas subjetividades, seria nas cidades que vicejariam essas formas de 
sociação definidas por sociabilidade, que não deixam de se manifestar como troca entre os indivíduos "livres" marcados pelos cálculos do distanciamento que presidem muitas das relações em contextos racionais e instrumentais. Dessa maneira, as relações não prescindiriam de algum start, de algo que as colocasse e partisse de um estado zero de sociação para se efetuar ou promover alguma disposição para a troca.

O futebol falado é lugar da sociabilidade e espécie de relé que aciona retóricas aparentemente fugazes e imitativas nos discursos da vida cotidiana. Saber para que time torce um desconhecido nos encontros face a face do dia a dia produz uma espécie de mapa cognitivo por onde as trocas podem ser estabelecidas. Brincadeiras canônicas embutidas na pergunta sobre o time de preferência do outro ou mesmo apelar para o acaso em adivinhar e chamar alguém disso ou daquilo como tentativa de burlar o anonimato e arriscar alguma empatia e proximidade prazenteira não passa de uma decisão ou tentativa de entrar no jogo da sociabilidade que visa, decerto momentaneamente, aproximar desconhecidos ocasionalmente colocados no torvelinho das interações.

Assim, parece que sociabilidade simmeliana também se revela no jogo incerto que antecede trocas efetivas (de coisas, de afetos, de informações, de desejos, pontos de vista), turning point em que os conteúdos a serem explicitados pelos agentes ganhariam os contornos da negociação para se evitar recusas ou conflitos, velados ou abertos. Sociabilidade mobilizaria seus próprios conteúdos (a falação no futebol é um caso), qualificados de estratégicos, combinando inúmeras maneiras expressivas em função da economia simbólica em gerenciar interesses divergentes. Aqui a dimensão da imitação se coloca como expressão fundamental na elaboração dessas "proximidades" que se servem dessas funções pragmáticas da fala cotidiana.

Pode-se aproximar sociabilidade simmeliana às relações jocosas, pensadas na dinâmica dos jogos sociais sugeridos por Radcliffe-Brown (2013a, 2013b) ao observar contextos etnográficos em sociedades "outras". Ali relações jocosas estariam entre as relações de solidariedade, sendo o parentesco o recorte paradigmático de um modelo estabelecido por leis da descendência, onde a ordem hierárquica moral supostamente seria preservada no concerto das relações, e as formas assumidas pela alteridade, ou seja, hostilidades e inimizades potenciais objetivadas em amizades formalizadas pela jocosidade e licenciosidade, fatores que poderiam acossar o tempo todo a paz homeostática 
primitiva. ${ }^{8}$ Relações jocosas seriam uma espécie de abertura quase teatralizada ou concessão dinâmica imposta à diferença envolta num mar de identidades.

A partir dessas tradições disciplinares, e voltando ao nosso problema conceitual central, antijogo acaba posicionado como espaço intersticial da sociabilidade, mas que pode perigosamente distanciar-se dos manejos e acordos da convivialidade, se pensado como espécie de matéria escura que divisaria os campos possíveis de expressões individuais, dilacerando a dinâmica dos jogos sociais. Daí, dessa perspectiva é preciso que se mantenha atado às propriedades da imitação e/ou sublimação de regras "sociais". Se pensado como mais um experimento da sociação, antijogo recalcaria a própria onipresença das regras ao redor de si, fazendo apenas uma leve sombra ao maciço de códigos, leis e regras de conduta que presidem os jogos sociais, formas societárias estilizadas voltadas para a busca de identidades ou tipos sociais, muito próximo daquilo que Simmel definiu por "realidade", ou diria ainda realidade imitativa da vida cotidiana eivada de situações pré-prontas. Se mantido dentro desse registro da noção de sociabilidade simmeliana, antijogo parece suscitar pouco estranhamento epistemológico entre identidade e diferença, se colocando apenas como um caso particular ou episódico do apanágio da igualdade.

\section{Social imitativo}

Mantendo ainda as considerações dentro dessa atmosfera da sociologia e antropologia clássicas, tomo partido da ideia de que antijogo possa expressar ou se agregar às noções de movimento imitativo como diferença e não reiteração, na esteira de alguns autores que pensaram a diferença como pressuposto de seus arcabouços teóricos e paisagens etnográficas. Um deles seria Bateson (2008), para quem as relações sociais manifestam-se sobretudo a partir de dinâmicas que ele define por cismogênicas, grosso modo, produção contínua de diferenças performatizadas que desacomodariam um certo mecanicismo analítico alicerçado na noção de equilíbrio e ordem funcional muito presente

8 Trata-se de "rivalidades entre parentes e aliados" (Mauss, 2001, p. 457), tal como salienta Mauss já em 1926, aliás, tema antecipado por autores como Lowie, seguido por Radcliffe-Brown em textos consagrados, sobretudo escritos nos anos 1940 (Gastaldo, 2010). Desdobramentos desses autores sobre relações jocosas e uma aproximação com a noção de sociabilidade simmeliana, tratando do tema dos torcedores de futebol, podem ser consultados em Gastaldo $(2005,2010)$. 
nas etnografias de seu tempo. Cismogênese procura responder aos processos diferenciantes acumulados pelas interações entre indivíduos e/ou grupos, estabelecendo duas formas possíveis, a complementar e a simétrica. Sendo a primeira motivada na evolução de relações que embora distintas e opostas; por exemplo, condutas assertivas de uns, respondidas com submissão de outros, acabariam produzindo uma proximidade entre esses agentes até o limite que o sistema poderia suportar. Já a cismogênese simétrica evoluiria pelo estímulo de mesmos referentes, quer dizer, as interações levando ao máximo de diferenciação também sob o risco da insurgência e conflito aberto.

Parece cabível também tomar ciência de algumas das formulações de outro autor clássico, Gabriel Tarde, que propôs, ao estabelecer a noção de imitação, um afastamento do sentido ordinário de representação (Themudo, 2002) e, acima de tudo, da noção aparentemente intuitiva de que a cópia guardaria com o original somente relações de identidade, quiçá totalidade. Tal proposição pode sugerir que, desde que tomada apenas por seus efeitos de identidade, a cópia quando mal realizada e/ou acabada revelaria tão somente os contornos de uma espécie de fracasso material e estético ou, no plano moral e ético, algo de farsante e burlesco. Mas também o inverso pode flagrar a mesma miragem em relação à onipresença da identidade, e, voltando ao antijogo no futebol e nos esportes em geral, penso nas situações em que a cópia poderia revelar não precariedade ou falta, quebrando o princípio identitário mimético, mas justamente o oposto, ou seja, o uso excessivo e imodesto das técnicas, um hiper-realismo que igualmente poderia colocar a ação fora do timing, produzindo algum afastamento pernicioso em relação às atitudes ditas normais e coletivamente esperadas, tomadas como fonte de equilíbrio, seriedade e identidade. ${ }^{9}$

9 Um caso singular transformou-se em controvérsia e exemplo paradigmático de antijogo no futebol brasileiro: as embaixadinhas (domínio técnico e teatral com a bola) feitas pelo jogador corintiano Edilson numa final de campeonato paulista entre Palmeiras e Corinthians no ano de 1999. O jogador reteve a bola e passou a executar malabarismos, paralisando o jogo até que alguns adversários, Junior e Paulo Nunes, rispidamente o deslocassem, causando uma desavença generalizada dadas as circunstâncias do jogo que favoreciam o Corinthians ao título. Tal atitude passou a ser interpretada como "cera", mas também desrespeito profissional, isto é, ao ganhar tempo prendendo a bola em demasia e se recusar a colocar o jogo em movimento coletivo. $\mathrm{O}$ jogo foi encerrado aos 30 minutos do segundo tempo devido às brigas. Há farto material escrito e visual que trata das "embaixadinhas" disponibilizado e de fácil acesso na internet. O modelo eliseano (Elias; Dunning, 1992) que preconiza o equilíbrio das tensões como fundamento dos esportes vindos dos jogos claramente se aproxima desse caso. 
Para Tarde imitação deve partilhar com a noção de invenção a primazia ou o locus originário da produção da vida. E sua teoria vitalista é apreendida por comentadores que destacam esse aspecto:

Não se poderia falar em uma repetição mecânica das séries imitativas disparadas por uma invenção, pois os componentes ordinários da série são também indivíduos passíveis de instaurar na série uma nova singularidade, produzir uma nova ideia que faça a série divergir. A imitação dá consistência, institucionaliza os símbolos e ritos sociais, cria uma memória, enquanto a invenção é a potência renovadora (impessoal), espírito errante, nômade, que vem sempre abrir uma nova variação no enredo da vida social e desejante. (Themudo, 2002, p. 24).

Essa discussão poderia levar ainda até a uma outra forma oblíqua de perceber a imitação como socialização dos indivíduos a partir de um "fora", noção epistemologicamente perniciosa para os propósitos deste artigo, assentada na ideia rotinizada de que a noção de sociedade fora abstraída e definida como entidade antitética "em relação a entidades de ordem conceitual semelhante: sociedade contra a economia, o mundo material e até mesmo a biologia ou a natureza", como salienta Strathern (2014, p. 233). Mauss e tantos autores posteriores recalcariam essa ideia: “É graças à sociedade que há uma intervenção da consciência [...] É graças à sociedade que há segurança e presteza nos movimentos, domínio do consciente sobre a emoção e o inconsciente" (Mauss, 2003, p. 421).

As implicações maussinanas fazem da imitação uma engrenagem de transmissão a serviço de um estado de consciência e fato da educação, mantendo no primeiro plano a noção de exterioridade dos fenômenos em relação aos indivíduos. Já Strathern, alterando esse eixo epistemológico centrado na dicotomia indivíduo e sociedade, focará as relações e chegará à noção de pessoa integralizada. Examinando um caso específico do parentesco em contexto britânico e tecendo sua crítica às teorias clássicas que pensaram o estatuto da totalidade via parentesco, comenta:

[...] a pessoa era um indivíduo completo. Mas o que tornava a pessoa um indivíduo completo não era o que a tornava parte de qualquer identidade mais ampla. O indivíduo era incompleto em relação à sociedade - devia ser completado pela socialização, pelas relações e pela convenção. (Strathern, 2014, p. 256). 
Roy Wagner, ainda dentro dessa mesma discussão sobre o estatuto da noção de pessoa, reverberando as análises de Strathern, lançou mão da noção de pessoa fractal (Wagner, 2011), que retomo bem mais adiante nas considerações finais.

Sustento, então, que antijogo possa ganhar potência agentiva como expressão das variadas formas pelas quais a diferença se expressa em tensão com as noções de totalidade e identidade, não raramente acomodadas numa dialética dentro daquilo que Roy Wagner define como modos de simbolização convencionalizante e diferenciante. Voltaremos ainda neste artigo a essa outra maneira de se colocar o mesmo problema da autonomia das categorias alicerçadas na diferença.

A questão agora passa a ser então o quanto e como os indivíduos podem ou não relativizar e improvisar o modo simbólico que os envolve e é nesse sentido que as extensões metafóricas e analógicas funcionariam de uma perspectiva wagneriana, quer dizer, não somente ou exatamente como rebatimento na linguagem de "estruturas" como que transladando os mesmos regimes convencionais da cultura de um lado para outro (por exemplo, da fala de senso comum para o discurso científico, de uma técnica corporal a outra no processo imitativo de uso e aprendizado), mas como efeitos de contextos e mundos inacabados.

Classificações simbólicas (codificações referenciais que medeiam a percepção e o mundo) são para autores como Roy Wagner apenas parte dos fundamentos que nos levam à simbolização humana uma vez que ações, motivações e as experiências sensórias (imagens) também participam desse constructo da significação (percepção, signo e sentido) não como representações (uma coisa representando outra mediada por signos), mas como relações (de uma coisa com outra sendo que ambas reteriam tanto a potência da condição de significado quanto de significante, ou como ele diz, símbolos que representam a si mesmos).

A noção de sentido, que estenderia à minha revelia para a noção de imitação, como simples efeito dos signos ou subordinado a eles leva à nomeação desses sentidos em detrimento da ideia de que os sentidos já seriam expressão simbólica, quer dizer, não seriam simplesmente os efeitos secundários ou objetos da linguagem impostos pelas convenções culturais (educação) e interiorização das normas sociais, cuja captura desses sentidos só pode ser realizada a partir de constructos já em andamento, digamos assim (Wagner, 2017). 
Estamos diante de outros paradigmas em que é a identidade que aparece como um caso particular da diferença, e as ações e relações nunca cessam de exprimir novos sentidos (Wagner, 2017), que nunca cessam de metaforizar outras metáforas. Simmel parece ao menos ter aberto o espaço para que a noção de sociação começasse a subtrair do conceito de sociedade seu campo existencial epistemológico próprio, deslocando o conceito de sociedade e o manejo do simbólico atado às representações coletivas e aos princípios da solidariedade. Outros depois dele, ou contemporâneos a ele, avançariam sobre o caráter instável e infinitesimal (Tarde, 2003) de captura e percepção do mundo na produção de contextos e conexões parciais (Strathern, 2012, 2014) de domínio das relações. ${ }^{10}$

\section{Antijogo, antítese de jogo?}

É preciso reconhecer que essas supostas regras estão repletas de exceções, e que a evolução linguística, jurídica, política, econômica, artística e moral, não são uma via única, mas uma rede de vias onde as encruzilhadas abundam. Tarde (1907 apud Themudo, 2002, p. 22)

A condição estabilizada que tal noção em seus usos correntes assumiu impediu que fosse tomada como potência geradora de sentido, revelando-se pouco além

10 Duas citações para ao menos instigar o leitor. A primeira sobre a potência do infinitesimal como instância das transformações (orgânicas, sociais) em Tarde (2003, p. 26), que leva à ideia de que qualquer entidade (um ser, um indivíduo tomado em sua singularidade) pode ser revelada pela soma de diferenças que a constitui (ou constitui sua identidade) em movimento: "De qualquer maneira, os verdadeiros agentes seriam, portanto, esses pequenos seres que dizemos ser infinitesimais, e as verdadeiras ações seriam essas pequenas variações que dizemos ser infinitesimais." Strathern (2012, p. 205), a respeito das conectividades parciais que produzem a pessoa na Melanésia e respondendo a uma pergunta sobre qual a sua concepção de história e mudança, diz: “Tomando os homens como exemplo, em um momento, a questão é pensar no clã, na mentalidade do clã, em outro, é pensar a si próprio como imerso dentro em um nexo individual de relações que ninguém mais possui. Há uma alternância entre os estilos de sociabilidade, pessoas se reunindo e pessoas se separando - de modo que elas produzem estados alternativos, tais como iniciados e pré-iniciados; ou como os momentos em que se revela e se esconde o mundo." 
de mera antítese de jogo, numa fórmula condensada do tipo regra e quebra da regra. ${ }^{11}$ Também matriz de metáforas, antijogo pode devolver à forma estilizada que a noção de jogo alcançou a matéria viva que especula, age, imita, transforma, copia, movimenta, constrange a suposta forma autônoma e inerte à qual muitas vezes a noção de jogo foi confinada, sobretudo quando assumida como prática esportiva de espetáculo ou, do ponto de vista culturalista antropológico, manifestação ritualística de identidades e nacionalismos. ${ }^{12}$

Frequentemente estendido ao repertório presente em outros discursos e domínios em que algum modus operandi competitivo entre indivíduos e coletivos se impõe, antijogo aparece também na economia e na política, lugares em que sinonimizações como "jogo sujo", "jogo ou golpe baixo" impõem o linguajar que se crê ríspido nas dinâmicas da parlamentarização, ${ }^{13}$ que parece um caso particular de sociabilidade. E aqui a imagem de antítese mais que se desdobra: "desonestidade", "abuso", "desrespeito" e falsificação sinonimizam sua expressão vernacular e delimitam, diria que restringem, as qualidades definidoras do campo extensivo que os significados de antijogo possam reter. As demandas nos jogos retóricos da linguagem cotidiana aparentemente recalcam tais

11 Essa é uma discussão que leva à problemática mais geral sobre regras esportivas. Nessa direção sugeri em outro artigo uma abordagem das regras do futebol utilizando as metáforas do quente e do frio como valências de reclassificação conceitual (Toledo, 2008). Noutra direção e problematizando uma sociologia crítica das moralidades consultar o importante artigo sobre fair play (Brito; Morais; Barreto, 2011).

12 Há, mais contemporaneamente, todo um movimento interdisciplinar nas pesquisas brasileiras para mapear os futebóis numa contraposição aos modelos mais francamente atados às relações de identidade. Os trabalhos de Damo (2007) contemplam e até mesmo anteciparam ou ainda conferiram algumas fissuras às imagens ou concepções mais monolíticas a respeito do futebol. Diria que esporte-nação seria uma projeção culturalista que se acomodou na antropologia e o esforço do momento é trazer os múltiplos fenômenos futebóis e sair do encantamento da identidade nacional como problemática central para se pensá-lo. Esse movimento que mobiliza muitos atores e que é transdisciplinar pode ser verificado em ações como a do Museu do Futebol, localizado em São Paulo, denominada de "Futebóis: pluralidade e representatividade": no fôlder de convocação pública para o encontro ocorrido em 20 de fevereiro de 2019 lê-se: “O Museu do Futebol busca renovar sua exposição, curada para a abertura em 2008, e quer fazê-la a partir do diálogo com diferentes pessoas que pensam, praticam, torcem e atuam com o esporte. Passados mais de dez anos, muita coisa mudou no futebol brasileiro e no modo como o Museu e a sociedade vê o esporte, que é também uma expressão cultural no país."

13 Uso parlamentarização aqui na exata medida em que Norbert Elias confere ao termo, ou seja, a produção de mundos sociais normativizados, o que ele adjetiva, e aqui me afasto do autor, de processo civilizatório. 
significados que aparecem supostamente estabilizados nas sentenças morais e éticas de variadas condutas. É preciso cautela diante dessa visão moralizante que, tal como a definição em epígrafe lá do início do artigo, laminaria o jogo contínuo e imprevisível de suas metaforizações.

Em tempo, tomo aqui este tropo na acepção atribuída por Roy Wagner, para quem as relações sociais são permeadas por metaforizações contínuas em que os sentidos, e a despeito do modo simbólico que se precipita das ações ditas "sociais", sempre estão sujeitos às invenções dos agentes, quer dizer, mais precisamente o autor nota que

todas as simbolizações dotadas de significado mobilizam a força inovadora e expressão dos tropos ou metáforas, já que mesmo símbolos convencionais (referenciais), os quais não costumamos pensar como metáforas, têm o efeito de "inovar sobre" (isto é, "ser reflexivamente motivados em contraste com") as extensões de suas significações para outras áreas. (Wagner, 2010, p. 17).

Nesse sentido antijogo poderia ser percebido numa dialética sem síntese (Wagner, 2010) com a ideia de jogo, bem como contrapartida diferenciante que não estaria a serviço da mera projeção contrastiva na reprodução de formas puramente convencionais das regras e normas (esportivas e tantas outras). Pode ser tomado não somente como decisão de ordem simbólica ou da natureza estilizada da sociação, afastando agora das formulações simmelianas, mas como produto das atividades, atos, corporalidades, subjetividades que expressam uma natureza propriamente política no sentido de que "talvez devêssemos buscar uma apreensão holística da maneira pela qual nossos sujeitos de pesquisa desagregam seus próprios construtos" (Strathern, 2014, p. 242).

Ou seja, faz-se imperativo contemplar a projeção de "imagens de dissolução" contrárias à ideia de que a sociedade "abrange os conceitos de organização e regras como desdobramentos seus [...]" tratando "de uma ordem contra a qual um ator individual construía suas ambições ou experiências", bem como "imaginada como um objeto de 'representações' externas", porém "mistificando formas de dominação como se certas pessoas estivessem agindo 'no lugar de' ou 'em nome da' sociedade" (Strathern, 2014, p. 235-236, grifo meu).

Nessa linha, seria mais produtivo, em suma, que as análises se cercassem da ideia de que antijogo, antes de mais nada, constitui uma política subjetiva 
da vontade, que produz contrapontos aquém e/ou além das esferas normativas que enredam os indivíduos. Comumente antijogo tende a se acomodar em condutas individuais, obviando a potência convencionalizante como instância que educará a "natureza" indômita presente no ser individual, antes mesmo que ele possa ser tomado como homem total ou pessoa como um todo (Strathern, 2014). Buscar as "imagens de dissolução" na noção de antijogo pode oferecer um contraponto à mera imagem da simulação e disfarce que persistentemente o acompanha.

\section{Antijogo e violência}

Diz-se que não se pode falar de jogo sem levar em conta o antijogo, a quebra da regra, a transgressão à norma e a violência instaurada em ocasiões de simulação controlada dos conflitos em performance. Lembrar que toda performance, sobretudo as ditas esportivas, instaura algum tipo de dilema ou conflito simulado, seja com o próprio corpo e seus limites tangíveis, seja com outros corpos em interação, situações-limite que dão os contornos à prática e conferem o que muitos autores definem por emoção. Não obstante, a produção da emoção esportiva pelo descontrole e não pelo controle das pulsões ou por intermédio do regime de regras estáveis e reificadas pode ser uma via heurística interessante para se pensar o antijogo não somente como lugar de exceção.

Esse foi um tema caro presente na escola configuracional e na sociologia do esporte inaugurada pelo pensamento de Norbet Elias e seguidores, que confinaram noções correlatas ao antijogo na esfera da sensibilidade psíquica voltada para os manejos da violência. O sofisticado modelo eliseano em que a vida social se constitui por cadeias de interdependência propôs escapar das noções mais metafísicas de sociedade, repatriando o espaço existencial do indivíduo para dentro de uma perspectiva sociológica (Elias, 1993).

Em que pese a importância dessa grande angular sociológica proposta e toda contribuição em pensar a violência em contextos controlados, essa vertente sócio-histórica carrega algo de unidirecional expresso na ideia de processo civilizatório. Manifestações delimitadas como práticas insurgentes, ou, melhor exprimindo, táticas de antijogo ou ainda formas não mais consentidas pela sensibilidade coletiva e individual, tomadas como manifestação da violência em períodos históricas sucessivos, manteriam nessa chave explicativa 
o fato da normatividade como substrato valorativo universal e inalienável como índice desse processo transformacional das sociedades em estados civilizacionais.

Como venho salientando não é exatamente ou somente pela via da antítese que pode ser pensado o antijogo como fenômeno constitutivo ou associado ao jogo. Creio que essa noção se espraia e invade outras esferas da socialidade esportiva, é farinha e fermento dela, mas dela se emancipa para reinventar ou antecipar outras socialidades, às vezes alheias aos propósitos do jogo, produzindo alteridades com ele e o constrangendo de outros lugares, sem necessariamente participar do consentimento ou quebra de suas regras, de suas modas, de suas marcas.

Antijogo não está numa relação simétrica e invertida à condição do jogo, pois pode ser pensado como instabilidade, agregando outros elementos em causa, produzindo associações impensadas, instigando emoções e desfechos inusitados, mas não exatamente uma emoção esportiva assentada na fortuna da performance (o gol, o recorde, a marca, etc.), e sim a emoção suspeita, duvidosa, transgressora, enfim, numa metafórica sinuca de bico imposta ao próprio jogo, para usar aqui uma bela expressão popular vinda de um jogo. E, como afirmou certa vez o automobilista Nelson Piquet, expressando aquilo que foi detectado como falta de decoro esportivo, as pessoas querem mesmo é assistir os acidentes espetaculares numa corrida de Fórmula $1 .{ }^{14}$ Poderiam multiplicar esses exemplos em que atitudes antijogo se manifestam à revelia da justaposição às regras como valor seguro para se alcançar a emoção. Dimensão fugidia, 0 antijogo esgarçaria as motivações do próprio jogo, daí sua dimensão metodológica de estranhamento necessária às dinâmicas que preside.

Antijogo não tem protagonistas fixos e mesmo aqueles guardiões da ordem podem praticá-lo inconscientemente ou inadvertidamente e seu real motivo seria a instabilidade como região normativa da esfera lúdica. Não necessariamente coincide com violência física esportiva ou sociabilidade esportiva contendora e, desse modo, seriam seus efeitos e não as intencionalidades (representações) em causa que secretariam toda a sua potência disruptiva, ainda que considerada efêmera em muitos casos.

14 Comentários que o piloto agregou ao opinar sobre a trágica morte de outro piloto de expressão mundial, Ayrton Senna, publicamente reconhecido como um desafeto de Nelson Piquet. 


\section{Antijogo e criatividade}

As observações em relação a essas formulações, estabelecidas e abrigadas em vários matizes conceituais, tornam-se reféns da problemática geral que parece não abandonar alguns pressupostos epistemológicos como o da externalidade das naturezas que cercariam o mundo social. E sem dar conta de que a própria ideia de externalidade, bem como a de fenômenos a ela solidários, participam das categorias que tentam explicá-los, mantém-se a presunção de que o mundo fenomênico é constituído de um "fora", exprimindo alguma natureza indômita que deveria ser domesticada pelos processos da convenção simbólica em termos de controles econômico, político, científicos (natural, psíquico e sociológico).

A constituição desse "dentro" e "fora", em última análise, do sujeito e do objeto, faz parte de uma dialética entre o que pode ser considerado inato e o que pode ser considerado adquirido, definidos, segundo Roy Wagner, como expressões simbólicas que operam no mundo dos significados. Para o caso das sociedades ocidentais ditas modernas e metropolitanas, como assinalava Simmel, essas que inventaram os esportes e seus praticantes (Elias; Dunning, 1992), e acrescentaria seus antijogos, Roy Wagner $(2010$, p. 123) adverte que

[...] todo o nosso leque de controles convencionais, nosso "conhecimento", nossa literatura sobre realizações científicas e artísticas, nosso arsenal de técnicas produtivas, são um conjunto de dispositivos para a invenção de um mundo natural e fenomênico [inato]. Ao assumir que apenas medimos, prevemos e arregimentamos esse mundo de situações, indivíduos e forças, mascaramos o fato de que o criamos.

Roy Wagner é um autor que oferece uma teoria do simbólico ampla o suficiente para que determinadas fronteiras, por exemplo, entre inato e adquirido, indivíduo e sociedade, ou aquelas que delineiam culturas ou que sustentam enfoques etnográficos, como etnologia e antropologia urbana, ou que motivam o embate com a história entre evento e estrutura, possam ser problematizadas ao se perspectivizar modulações entre dois modos de simbolização mobilizados pelas convenções que ele denomina de diferenciante e coletivizante. Para esse autor "diferenciação" e "coletivização" seriam abstrações abrangentes e estilos 
de ações humanas que se inventam mutuamente o tempo todo e que motivam uma dialética sem síntese presente em qualquer regime cultural, seja nas ações ditas sociais, seja nas ações individuais. Estas últimas, aqui no caso, mais sensíveis às categorizações dentro daquilo que frequentemente é tomado por antijogo.

Acompanhemos mais uma citação:

[...] para qualquer conjunto de convenções dado, seja ele o de uma tribo, uma comunidade, uma "cultura" ou uma classe social, há apenas duas possibilidades: um povo que diferencia deliberadamente, sendo essa a forma de sua ação, irá invariavelmente contrainventar uma coletividade motivadora como "inata" [caso de muitas sociedades indígenas e extratos menos favorecidos no interior de nossas próprias sociedades], e um povo que coletiviza deliberadamente irá contrainventar uma diferenciação motivadora dessa mesma maneira. (Wagner, 2010, p. 95).

Portanto, inato e adquirido seriam convenções da ordem da cultura ou o modo como sociedades ou mesmo grupos sociais produzem ou inventam sua própria cultura fixando como controle um e outro desses universos. Ambos os modos de simbolização estão presentes nas ações tanto de indivíduos quanto de coletivos. Sociedades próximas às euro-americanas primariam pelo primeiro modo ou estilo de simbolização. Já o modo de simbolização diferenciante seria aquele que "provê o único regime ideológico capaz de lidar com a mudança" (Wagner, 2010, p. 16), presente em sociedades ditas não ocidentais ou na ação de grupos ou indivíduos mais insurgentes e "criativos" no interior das sociedades ocidentais.

Tal aspecto motivador e criativo pode ser verificado em vários domínios, que o próprio autor identificará primeiramente ou primordialmente no mundo físico e natural, contrainvenção do domínio político e do discurso científico. E aquilo que se define por natureza seria, em última análise, uma invenção e um mecanismo de controle para que o regime de convenções simbólicas possa se estabelecer como simbolismo hegemônico. Portanto, o esforço é controlar todos os regimes que simbolicamente são definidos por "naturais", seja o mundo externo, daí as rotinas científicas institucionalizadas que visam controlar a indômita natureza, seja um mundo "interno”, daí uma psicologia e uma 
psicanálise em torno das criatividades do "eu". Já ao pensamento sociológico e suas áreas correlatas caberia explicar ou controlar a natureza externa, portanto "social", dos fatos que precipitam a vida em sociedade.

Encaminhando o argumento nessa direção, antijogo expõe sua face criativa como contrainvenção inovadora e em muitos aspectos insurgente ao relativizar os controles definidos convencionalmente nos regimes esportivos, que confinam as dimensões lúdicas e as conferem alguma "seriedade", ou aquilo que Simmel acreditava estabelecer para sua definição estilizada de sociabilidade: "uma relação profunda e fiel com a realidade". E não é por acaso que toda atitude que leva essa pecha de antijogo acaba colocando em risco alguma ordem convencional, não raramente definindo a ação assim tipificada pelo seu suposto irracionalismo inerente (inato), fruto de descompensações de natureza psíquica de seus agentes motivadores ou instados por convicções religiosas e ideológicas impregnadas na pessoa. ${ }^{15}$

Enfim, passemos a alguns excertos etnográficos pontuais e fragmentados para arrematar o artigo e tentar traçar os alcances e/ou limites que uma decisão metodológica pelos usos de noções mais à margem como antijogo podem oferecer. Sempre é bom lembrar que o intuito deste artigo é tentar ampliar as possibilidades de estudar fenômenos confinados mais à penumbra das esferas normativas ao lidar com categorias da diferença.

\section{Etnografando antijogos}

\section{Uma tarde no museu}

A tese de doutorado de Alfonsi (2018) ${ }^{16}$ traz uma interessante discussão antropológica sobre objetos curados e representações futebolísticas. Caminhando pelos espaços expositivos do museu do futebol escocês em Hampden, defrontou-se com uma curiosa relíquia, assim descrita:

15 Para uma análise sobre "rebeldias" políticas no futebol, consultar Florenzano (1998).

16 Para uma análise mais detida sobre o Museu do Futebol implicado na tese dessa autora, recomendo Toledo (2019). 
Uma escultura busca capturar um momento da primeira partida internacional ente seleções de futebol, durante o qual três jogadores se chocam de forma violenta. Curiosamente a bola não aparece nessa escultura, e a única forma de identificar que os personagens retratados são jogadores de futebol é o uniforme que vestem. Ao chão, dois integrantes da seleção inglesa, como que humilhados por um aparentemente mais hábil escocês que, de pé, pisa nas costas de um dos jogadores ingleses. Ao fazer apologia de uma típica cena antijogo, a escultura discorre sobre a rivalidade dos escoceses contra os ingleses e revela o desejo por triunfo sobre a nação que posiciona a Escócia em lugar coadjuvante no mundo do futebol [...]. (Alfonsi, 2018, p. 148).

Há dois desdobramentos possíveis, ou metáfora sobre metáfora, sugeridos nessas observações in loco realizadas pela etnógrafa: primeiro a ideia de que, como já notei muito lá atrás, uma certa falsificação ou produção de fabulação histórica se faz presente na tentativa de inverter uma ordem hegemônica política e esportiva imposta pelo protagonismo inglês, e, segundo, uma seguida metaforização reposicionando uma jogada assertiva identificada pela autora como manifestação de antijogo como fundante de um estilo de jogar contendor, transfigurado no mesmo contraste político na forma de uma técnica corporal vitoriosa, a pisada nas costas do adversário. ${ }^{17}$

Parece que se está diante de um exemplo em que processos históricos cismogênicos inconclusos se colocam à disposição estética na forma escultural. Antijogo assume ou substitui aqui a noção de jogo numa refrega real ou fictícia (pouco importa) que em princípio deveria estar sob a égide universal das regras e da beleza estética das técnicas exibidas no desempenho dessas duas seleções. Antijogo revela o seu potencial disjuntivo, uma ressemantização, e diria que se está diante também de um paradigma novo ao se desconceber os fundamentos

17 Fui advertido que a pisada (supostamente ocorrida num jogo real) poderia à sua época ser considerada um recurso corporal legal e que somente a posteriori fora enquadrada na moldura das regras que legislam sobre violência dentro do campo. Discuti modulações e internalização das regras do futebol em Toledo (2002), todavia mantenho e corroboro a estranheza da etnógrafa por falta de maiores detalhes sobre uma suposta primeira partida entre as duas seleções. Importa que nomear a jogada de antijogo nos leva a pensar as normas, ainda que algum anacronismo nessa interpretação venha a se interpor. 
da ordem esportiva presente em uma partida de futebol por intermédio dos usos de um antijogo produtivo ostentado pelo museu.

Desfaz-se uma noção normativa de jogo para refazê-la em outro plano, expressa em alguma ideia de nação reconstituída pelo avesso ou franjas de seu processo civilizatório. Processo em que o regime contrastivo (no caso entre nacionalismos locais) se colocaria como extensão metafórica levada às últimas consequências, multiplicando a produção dessas diferenças entre as nações. Desaparecem da representação escultural noções de jogo como sociabilidade prazenteira, fair play e ludicidade, ou competitividade entre iguais sob o manto das leis, mas também se relativiza a ideia de que aquele antijogo se prestaria a revelar-se tão somente como antítese de jogo ou ainda produto de cópia estética e técnica mal elaborada de uma partida "real".

Porque o antijogo ali tridimensionalizado, exibindo a pisada do futebolista escocês no jogador inglês, se basta como signo propulsor de outros jogos, no caso, os jogos cismogênicos políticos entre duas nações em performance e em contínua tarefa de produzir seus distanciamentos esportivos e ideológicos relativos.

A autora relata ainda na tese visitas a outros museus de futebol, sendo ela própria funcionária de um, tal como problematiza, e parece relevante depreender da leitura de suas incursões etnográficas o modo como os nacionalismos vão se singularizando, mas, sobretudo, se diferenciando imitativamente aos projetos ideológicos em museus esportivos. Por exemplo, o Museu do Futebol brasileiro do qual ela é uma das diretoras destaca um nacionalismo futebolístico de caráter mais culturalista (de certo modo apartado das querelas ideológicas); o museu do futebol chinês, com seu futebol inexpressivo em termos de resultados internacionais, preconiza um lugar político mais universalista, já o museu escocês reivindica seu nacionalismo dimensionando uma escala mais regional.

Deliberadamente e de modo geral o belo jogo e não qualquer cópia mal concebida aparece como apanágio definidor das curadorias expositivas na produção desses espaços museológicos pelo mundo afora. Todavia o exemplo da escultura, ou diria instalação presente no museu escocês, se revela como uma singularidade, testemunho do uso de um artifício vindo do antijogo como recurso ou categoria da diferença que desloca os nacionalismos e classificações esportivas ideológicas na perspectiva de seus fluxos reciprocamente imitativos. 


\section{“Algo a mais": o caso Luisito Suárez}

Não foram poucos aqueles que ansiaram naquela Copa do Mundo realizada no Brasil em 2014 por uma inédita final entre Brasil e Argentina. À época ouvia-se que as razões insuspeitas é que no fundo se queria ver um embate que transcendesse o futebol, que insuflasse amortecidos nacionalismos regionais, que hoje retornam em políticas arrivistas diante das crises que cercam países vizinhos como a Venezuela. Mas naquele momento tratava-se de atiçar outras diferenças para além da óbvia exibição das expertises futebolísticas corporalizadas nos maiores astros de ambos os selecionados, Messi, de um lado, Neymar, de outro.

A espera do suplemento simbólico expresso no "algo a mais", que não se confirmou na suposta "final das finais" entre brasileiros e argentinos, encontrava-se alguns outros atores menos incensados pela mídia que poderiam vazar da competitividade esportiva para a política, ou dos esportes para a cultura, entendida também como modo de se fazer nacionalismos.

Aqui antijogo poderia circunscrever aquilo que se definia de modo impressionista por "algo a mais", ou seja, o encadeamento de fatos e consequências que, inesperados, pudessem fazer aparecer o novo e ou o inusitado no âmbito daquela copa, ademais efeitos esperados que parecem estar por trás de qualquer competição esportiva, seja o futebol, o automobilismo ou as tradicionais corridas espanholas. Michel Leiris (2001) tinha absoluta convicção ao descrever o ponto de vista heroico e sacrificial do touro numa arena, deslocando a sensibilidade que hoje cada vez mais é capturada pela ordem racional imposta à fruição esportiva entre humanos. Limites que hoje uma antropologia multiespécie procura explorar.

Já a seleção do Uruguai esboçou afastar o fantasma de outras desclassificações precoces em copas depois de incríveis e até certo ponto inesperados triunfos sobre Inglaterra e Itália na primeira fase, e, protagonizando alguns dos eventos esportivos mais espetaculares, quase terminaria sua participação no evento da bocarra incontrolável do atacante Luisito Suárez desferindo uma mordida no defensor italiano Giorgio Chiellini. Amparados na memória de 1950, afinal a seleção uruguaia voltava ao país palco de seu maior triunfo, os uruguaios seguiam naquela cantilena avivando internamente e ao seu tempo histórico o peculiar nacionalismo esportivo refundado desde o maracanazo, 
onde a garra charrua revitaliza de tempos em tempos a eficácia simbólica da mística camisa celeste.

Muitos achavam que a conhecida garra charrua havia sido suplantada pela disciplina (tática, corporal e psíquica) e que perdera enfim a eficácia e potência anímica, ou estaria amparada apenas em discursos movidos pela nostalgia. Entretanto, prefiro defini-la como memória potencial que poderia ser ativada a cada lance, jogada ou trombada dos jogadores uruguaios em seus adversários em campo, ou emergida da tênue linha entre jogo e antijogo, onde uma inconfessa "sinceridade simbólica" (perdoem-me expressão tão esdrúxula) de que a violência física, o confronto e o incontrolável ainda fazem parte do futebol, pudesse vicejar mais uma vez, revelando o "algo a mais". O evento Suárez, desse ponto de vista, e a despeito da seguida desclassificação diante da Colômbia nas oitavas de final, intensificou o sistema de valores em torno da garra celeste, mais imune ao processo civilizatório que ampara a internacionalização do futebol.

Mas no que se refere à sensibilidade em torno do confronto físico, do embate corporal e valores que traçam as tênues distâncias entre o lícito e ilícito na conformação das regras, a mordida, minimizada no discurso dos uruguaios num primeiro momento, só pode ser avaliada se associada ao conjunto de valores que norteiam a ideia de garra charrua. Porém, não se deve deter ou ficar impressionado pelo ineditismo, quer dizer, na aparente pouca frequência do uso teatral de tal técnica corporal no futebol.

Cotoveladas que abrem supercílios ou ferem ainda mais gravemente oponentes, dedadas em regiões do baixo corporal ou nos olhos e toda sorte de intimidações sensíveis seguem uma lista criativa daquilo que é categorizado de ilícitos, na qual a mordida aparece apenas como mais uma contribuição ao repertorio futebolístico (quantas mordidas pelos campos de várzea, pelos baldios, não saberíamos mensurar!).

Não se está exatamente diante das circunstâncias sugeridas pela piada infame onde o algoz impõe à vítima a desafortunada escolha entre um tiro ou uma beliscada. E que, feita a opção pela segunda, tal vítima se vê desesperada diante de um alicate nas mãos de seu algoz. A mordida também é dotada de técnica, circunstância, presença. Faz, portanto, parte do universo de técnicas corporais que podem ser acionadas dentro de um repertório que não necessariamente decresce no futebol a despeito da crença nos meios tecnológicos que 
tentam inibir que tais atos ocorram, acabando com aquilo que se delimita por expedientes do antijogo.

Os inúmeros atos considerados violentos ou potencialmente ilícitos dentro do futebol guardam uma noção de conjunto e se associam a partir de um "fora" convencionalizado como sendo as regras que, enfim, definem o que se pode ou não fazer dentro de campo. Curiosamente a mordida causaria naquele momento a estranheza em relação a esse próprio repertório de coisas interditas, porque, na verdade, parecia algo impensado naquelas circunstâncias. $\mathrm{O}$ que fez a mordida foi alargar esse repertório, inovando sobre ele, inventando outra presença.

Capturá-la ou categorizá-la se fez necessário, pois tratá-la como se fosse algo à parte desse universo seria colocar em risco, aí sim, o modo como as "sociedades com bola" escolheram lidar com o futebol ao fronteirizar jogo e antijogo. Alguns preferem ver tal processo (positivado, diga-se) de diminuição da violência esportiva pelo olhar do psiquismo civilizacional, outros podem reivindicar outras coisas e tentar perceber que o inverso também pode ter algum lugar na história, enfim, que modalidades de violência e transgressão se especializam na mesma proporção, alargando as dimensões do controle via invenção de outras realidades. O velho hábito da mordida, recurso animalesco tão universal mesmo entre os filhos das civilizações, parecia debutar em Copas do Mundo e ali a controvérsia se deu em tentar reposicioná-lo dentro do universo ou conjunto normal das transgressões mais acomodadas à convencionalização do jogo.

$\mathrm{O}$ alcance ou os efeitos que aquela mordida desencadeou não foram muito mais além do âmbito esportivo até mesmo porque seu protagonista não é dado às polêmicas fora de campo. Mesmo assim, se tomada como uma espécie de singularidade, suas causas não permaneceram somente centradas no suposto atavismo e subjetivismo de Suárez, pois acabaram incidindo sobre o caráter asséptico que se quer impingir a um megaevento esportivo como as Copas do Mundo masculinas de futebol. O caráter não imitativo da mordida, em tese gesto que qualquer um poderia estilizar como técnica corporal, adveio antes de sua estranheza ou, digamos, natureza diferenciante que impôs ao regime de regras.

\section{La mano de Dios: a singularidade Maradona}

Maradona enfrentou o assédio após encenar aquilo que ficou nomeado por la mano de Dios, marco político esportivo dentro e fora dos gramados e que 
fora quase que imediatamente capturado em imagens e inúmeras cópias e reproduções que ad nauseam foram recriadas em vídeos, hoje em memes, replicadas nas redes sociais. Alavancando todo seu corpo de baixa estatura para ganhar alguns centímetros que lhe faltavam, objetivando alcançar a bola numa cabeçada, usou o expediente da mão, segundo ampla cobertura jornalística, uma estratégia oportunista, que, projetada na direção da meta adversária, o selecionado inglês, garantiu o primeiro de dois gols que levaram a Argentina até as semifinais da Copa de 1986, depois às finais e finamente à conquista do título.

La mano de Dios estava sob os rescaldos e a atmosfera densa de crises políticas após o ocaso do regime da junta militar e as querelas internacionais com os ingleses pela posse das ilhas Malvinas (Falklands), conflito ocorrido quatro anos antes. Fatos que contíguos e que somados aclimatavam aquela que era uma verdadeira partida de decisão com conotações de vingança. Os anos de democracia viriam dar o tom de outras crises e conjunturas políticas que transformariam o conflito das Malvinas numa fabulação contada e recontada como espécie de mitologia política facilmente capturada em momentos de enfrentamentos esportivos, de resto sensíveis e galvanizadores de identidades nacionais.

O populismo de Maradona aproveitaria esse caldo que misturava ideologias e futebol. A partida protagonizada por Argentina e Inglaterra nas oitavas de final se deu no interior dessa atmosfera um tanto impressionista, que embaralhava sentimentos contraditórios amparados numa aventura militar em retardar a queda de um regime autoritário com a noção de soberania esportiva que quase sempre serve como suplemento para atiçar as rivalidades entre seleções de países cujas histórias se enredam aos processos de colonialismo e independência. Além do título do torneio ter ficado com a Argentina, aquela foi a copa de Maradona, amealhando os prêmios bola de ouro na categoria atleta individual e bola de prata pela vice-artilharia do certame.

A matreirice se fez necessária, cumpriria os desígnios retroativos de uma nação em histórico litígio com os ingleses. Fora Deus, algum deus, afinal, que o auxiliou naquele gol diante do English team e a burla ganharia o mundo e seria reconhecida como la mano de Dios. A encenação da jogada foi reproduzida até com o brinquedo mundialmente conhecido, Lego, embaralhando as dimensões do jogo ainda mais com o plano da ludicidade. 
Ganhar a eternidade no panteão do futebol, derrotar um arquirrival a qualquer preço, regozijar-se com tal estratagema e ser reconhecido como portador do antijogo pode compor o feixe de motivações contraditórias em torno a Maradona. Os efeitos colaterais e possivelmente mais interessantes de tal gesto podem ser ancorados na desorientação dos expectadores, impondo aquilo que ambiguamente se percebe como apreciável ou não, feio ou belo, falseador ou legítimo numa partida de futebol, termos que num nível simbólico operam continuadamente diferenças. O contraste entre essas qualidades vale como índice de emoção e permanência desse evento na memória popular há décadas e não a supressão civilizatória de um termo pelo outro.

Desconcertante gesto ludibriador, misto de técnica futebolística apurada, presença e atitude tosca e antidesportiva, a escolha num átimo da "má técnica" em la mano de Dios se prestou a resgatar as atitudes mais irônicas de uma biografia que se forjou entre os baldios e seus anônimos convivas, lugar da periferia de Buenos Aires (Archetti, 2003), onde a burla grassa como constitutiva do jogo, onde à seriedade são impostos limites da brincadeira comum, entre comuns. La mano de Dios, assim, incomodou e incomoda justamente porque ficou aquém das expectativas daqueles que acostumados a domesticarem seus heróis esperam deles somente a correção, sensatez, justeza para canalizarem o potencial técnico na produção quantitativista do espetáculo futebol emulador de identidades (locais, regionais, nacionais).

É sabido também que Maradona se reconhece, mas sobretudo é reconhecido como um cidadão que representa uma posição mais à esquerda do espectro ideológico, flertando publicamente com regimes tomados por ditadura "comunistas" ou socialistas latinas (cubana, boliviana, venezuelana), espécie de antirregimes democráticos para muitos daqueles que se alinham ou se convertem às seguidas ondas neoliberalizantes e outros conservadorismos que ganham espaços geopolíticos importantes nas Américas da contemporaneidade.

Sua postura iconoclasta diante das instituições mais hegemônicas (Estados nacionais, a Igreja, a própria FIFA) pode ser capturada no seu estilo antijogo, e, em vez de tomar la mano de Dios como um gesto representacional maior do que seu inventor, por exemplo, dizer que a executou em nome da nação argentina, ele próprio jocosamente disse que se tratava da mão de Deus, ou mesmo tomar suas opiniões políticas por polêmicas meramente 
extemporâneas, deve-se levar a sério seu antijogo como sintoma de mudanças, índice de diferenças que estavam encubadas na platitude das regras e das ideologias acomodadas à direita ou à esquerda, bem como na cômoda ordem esportiva.

Incrementos tecnológicos para se evitar a burla e o antijogo passaram paulatinamente a fazer parte dos espetáculos futebolísticos, cada vez mais recheados de próteses que buscam ampliar para alguns, substituir para outros, os sentidos da emoção. Silenciar Maradona, por exemplo, tornando-o persona não grata em alguns países, e cito o episódio em que recusaram conceder lhe o visto americano, foram sinais indiciários de como as diferenças são tratadas numa nova conjuntura política, gesto que parece divisar, ou melhor, antecipar o jogo, ou o antijogo das políticas restritivas.

A polêmica em torno da construção de um muro monumental na fronteira entre os EUA e o México é a contrapartida "social" tardia daquilo que um simples gesto já havia despertado obliquamente e sem solução de continuidade naquela copa mexicana em que Maradona fora herói dos fracos diante de potências bélicas e esportivas. Retrospectivamente, hoje aquele gesto parece menos sinalizar para as questões que tratam de identidades nacionais ou vingança argentina frente os ingleses do que apontar para novos regimes de diferenças regionais que se movem, tomando feições democráticas relativizadas, quer dentro ou fora dos gramados, instauradas aqui e acolá. E, em nome de novas ordens ou ordenamentos racionais (esportivos, jurídicos, geopolíticos, econômicos, estéticos), la mano de Dios segue como possibilidade virtualizada de que novos gestos insurgentes para uns, burla para outros, possam descortinar muitas das ações que, amparadas em regras e representações que se pretendem estáveis, teimam em subtrair direitos, espaços existenciais, formas de jogo e fruição das emoções, sejam políticas ou esportivas.

Na Copa do Mundo de 2018, num jogo entre Argentina contra a Nigéria, suas mãos voltariam à polêmica, metonimizando mais uma vez as múltiplas faces de seu caráter considerado controverso. Excessivamente caçado pela transmissão televisiva que o apanhava em atitudes, gestos e trejeitos extravagantes pelos camarotes confortáveis, fora mais uma vez flagrado provocando torcedores contrariados com a sua permanência ali nas dependências do estádio. $\mathrm{E}$ ao comemorar a vitória argentina retribuiu a hostilidade, exibindo dedos em riste 
em cada uma das mãos (Dedo..., 2018), numa franca provocação considerada ofensiva e notada pelo diretor de competições da FIFA, Colin Smith.

Num determinado site ${ }^{18}$ tal gesto foi denominado de los dedos de Dios, qualificado como uma atitude "cafajeste" realizada pelo ex-craque. E tomado como cópia rebaixada e um clichê obsceno porque atado à realidade mais mundana, foi ironicamente contrastado com a outra gestualidade metafórica mítica e universalista que o consagrara, la mano de Dios, elevando-o à época da Copa de 1986, como já salientado, à condição de herói de uma nação.

Maradona, mais uma vez, agora em outra edição de Copa do Mundo, fazia história. Mas não exatamente a partir do recurso e uso de metáforas míticas e heroicas que levariam a alguma identidade nacionalista, tal como ocorrera com la mano de Dios. Lançaria mão de outro repertório, gestualidades, consumos excessivos deixados em aberto pelo jogo e comportamento próprio da condição histórica que passava a ostentar, a de torcedor, ou de um tipo de torcedor a reposicionar uma identidade regional.

Se para o pensamento conservador los dedos de Dios se tratava de um rebaixamento do herói a um mero simulacro do jogador excepcional que fora um dia, transformado em anti-herói, manifestação ainda mais rebaixada de seu antijogo, cumpre observar mais uma vez a perícia e presença de tal gesto teatralizado, singularizado na exposição de um realismo que, ao contrário do que se supõe, não se tratou de uma mera cópia rebaixada, sequer atitude desesperada de um craque que perdera a aura lançado agora no torvelinho imitativo supostamente presente no comportamento genérico dos torcedores.

Maradona, ao exibir francamente e compulsivamente suas emoções torcedoras, descortinava ali a universalidade do singular e da diferença, pois "a generalidade é dominada pelos signos da igualdade: cada termo pode ser substituído por outros termos que lhe são iguais. Ao contrário, só é repetido o que é insubstituível" (Waldman; Vogt, 1982, p. 95). ${ }^{19}$

18 A propósito, consultar Los dedos... (2018).

19 Aqui os autores estão citando Deleuze e a decisiva distinção que o filósofo faz entre generalidade e repetição, conforme Deleuze (1972). 


\section{Considerações finais}

Perspectivas antropológicas abrigaram a ubíqua questão da diferença em momentos que percorreram toda a história da disciplina, não raramente mantendo-a atada às noções de cultura, assumida em gestos êmicos ${ }^{20}$ que, partindo do espraiamento da atividade etnográfica, alcançaram a perspectiva mais geral e rotinizada na expressão "diferenças culturais". Nesse sentido, diferença particulariza, especifica, delimita e nomeia culturas distintas. Tal movimento pôde ser retido na instalação do museu escocês exemplificado a partir de Alfonsi (2018). Expressava-se ali um caso típico de diferença cultural entre jogadores ingleses e escoceses esteticizados naquela instalação antijogo, mas também se colocava em movimento alguma expressão ou sensualidade da diferenciação ao embaralhar as perspectivas, ou seja, ao trocar as competências e, digamos, devires históricos de uma e outra escola futebolística num processo de imitação criativa onde os escoceses é que seriam os jogadores mais técnicos e habilidosos.

Aqui, como já apontado, não se mobilizou uma definição positiva de diferença, e, tentando se afastar de uma ideia mais tautológica, ${ }^{21}$ quer dizer, em vez de tomá-la ou mantê-la em contraposição às escalas de identidade, partiu-se do pressuposto de que diferença difere. Para isso foi evocado em passagens anteriores deste artigo que em autores como Gabriel Tarde a diferença não se deteria no fato ou na presença das formas identitárias, uma vez que estas

20 Sigo Dulley (2014, p. 11): “Entendo por gesto êmico o gesto antropológico clássico que consiste na designação da alteridade por meio de nomes que em última instância indicam pertencimento a um grupo ou categoria com maior ou menor grau de delimitação." Agradeço a autora pelas discussões sobre os limites de se pensar os esportes, o nacionalismo neles expressos, penso o futebol em específico, fora da convenção e das totalizações retidas em gestos êmicos, tema que espero desdobrar em outras oportunidades.

21 Tautológica tal como aponta Gonçalves (2009, p. 78) ao discorrer sobre a perspectiva wagneriana: "Os significados lexicais, gramaticais, contêm uma arbitrariedade, portanto, são sempre tautológicos, podendo ser expressos em fórmulas do tipo: isso é um cachorro porque é um cachorro em oposição a um gato. Para Wagner é assim que construímos um sistema classificatório, sempre buscando significados tautológicos. Entretanto, são os significados não tautológicos os mais interessantes para se pensar o modo de representação e apresentação de um sistema cultural, visto que são produzidos através da inovação dos significados justamente pelos processos de metaforização. Para Wagner, a significação metafórica envolve uma não-arbitrariedade e uma indeterminação da relação entre significante e significado." 
constituiriam a aparência que ocultaria o trabalho por vezes silencioso da diferença sempre reposta em escalas da vida cada vez mais infinitesimais, assumida como espécie de (des)ordem constitutiva e constituinte dos fenômenos.

Tentou-se se cercar aqui da noção de diferença não no sentido mais substantivo, assinalada como um marcador social de diferenças, que geraria outra maneira de atestar somente fatos da identidade, ${ }^{22}$ mas diferença produto da relação dialética entre invenção e convenção instanciada na disjunção potencial entre modos simbólicos, tomando

os efeitos contrastantes dos modos de simbolização convencional e diferenciante [como] partes da dialética [em que] eles simbolizam um ao outro, [sendo que] [...] a simbolização convencional estabelece um contraste entre os próprios símbolos e as coisas que eles simbolizam [...] os símbolos diferenciantes assimilam ou englobam as coisas que simbolizam. (Wagner, 2010, p. 18).

É com esse escopo analítico, agora acrescido de outra analogia proposta pelo autor, fractalidade, que podemos retomar um dos exemplos etnográficos oferecidos há pouco para, finalmente, tentar arrematar a ideia de que a noção de antijogo pode, enfim, ser pensada como uma categoria da diferença.

Se Maradona voltou a utilizar as mãos naquela partida em que performava a condição de torcedor eufórico, recurso expressivo de seu nacionalismo que para muitos revelava o desvario de um ídolo decadente e fora de si, foi para exprimir ou inquirir novamente a diferença na e da realidade, instaurar, ainda que de modo fugidio, mas imitativo no sentido já aludido, outro contexto e não hipostasiar a generalidade das normas, regras e decoros pretensamente universais presentes em espetáculos futebolísticos. Mas também, e sobretudo,

22 Talvez seja nessa direção que um dos trabalhos pioneiros, na verdade um outro clássico, como A teoria da classe ociosa, texto de Veblen (1974) publicado em 1899, perceba o caráter identitário e de "sobrevivência" que os jogos assumiram na economia competitiva capitalista (economia pecuniária) numa contraposição às teses de sabor marxista que logo mais conceberiam as atividades esportivas somente na chave da alienação. Veblen parece inclusive antecipar uma perspectiva de campo bourdiesiano ao abordar o tema das estratificações não somente do ponto de vista economicista, daí assuntos como a moda ou os esportes aparecerem com vigor nesse texto inquietante, em que pesem as ideias correntes que compartilhava sobre raça e evolução (vai identificar o "primitivismo" na evolução da classe ociosa do sul dos Estados Unidos em comparação à do norte), que marcam profundamente seu texto. 
inquirir a condição incômoda que lhe fora outorgada como espécie de big men esportivo, ou mais precisamente a de ídolo de toda uma nação. ${ }^{23}$

Tais aproximações com a esfera das emoções e sociabilidade transgressora torcedora o recolocou numa aspiral fractalizante na medida em que exprimia formas e expressões presentes vindas sobretudo das arquibancadas. E, abdicando da posição de prestígio que a condição hierarquizante de ídolo lhe chancelava, aqueles gestos torcedores extravagantes, dedos em riste, pareciam colocar em dúvida à nação e ao mundo a escala cultivada da passagem de simples jogador de futebol à notoriedade pública que sua pessoa passou a ostentar, não sem controvérsias, ao término de sua carreira como atleta.

Essa torção fractal, se pudermos insistir nessa analogia, de um grande ídolo para um grande, embora mais um, torcedor, produziu um contínuo reversível entre sua pessoa e a totalidade torcedora, efetuada na exibição de um gesto inominável, expressão corporal coletiva e imitativa de antijogo, embaralhando as expectativas coletivizantes do decoro e da hierarquia que deveriam exprimir sua postura de ídolo ou big man esportivo, representante de uma nação no concerto das representações políticas esportivas. Curioso como muitas reações reiteraram que Maradona como pessoa sairia moralmente "menor" daquela situação ao alienar-se de sua condição de ídolo ou representante de um país e que tal gesto violentava a própria identidade argentina.

Vale acrescentar a perspectiva da fractalidade naquilo que interessa à analogia aqui, ou seja, seu princípio de reversibilidade mantendo certa escala no modo como as relações entre o ídolo e o coletivo genérico de torcedores permaneceram naquele momento implicadas num gesto considerado antidesportivo ou de antijogo.

E naquela "produção de constrangimentos" (Wagner, 1972, apud Gonçalves, 2009, p. 77) e representação de si mesmo, efeito estendido à mordida desferida pelo jogador uruguaio Luis Suárez, inovações que atentavam à moralidade universalizável presente no fair play (Brito; Morais; Barreto, 2011), expandiram-se as metáforas do comportamento mais comumente presente

23 A distinção entre big man e great man estabelecida por autores como Wagner (2011) ganha uma abordagem crítica em relação à própria diferenciação que sua obra sofre ao passar da perspectiva da invenção à fractalidade, tal como bem salienta Dulley (2014). Um leitor especialista por certo perceberá que minimizo aqui essa importante questão. 
nas arquibancadas populares, loci da sociabilidade antijogo menos sujeita aos manejos da cordialidade, para os camarotes oficiais e endinheirados do estádio. Ambos considerados antijogo, la mano de Dios ocorreu dentro do gramado, rasurando a insidiosa equidade das regras, los dedos de Dios ocorreram fora do gramado, no seio da sociabilidade torcedora estratificada de classes presente dentro do estádio.

Se anteriormente la mano de Dios contribuiu decisivamente com o título mundial da Argentina, posição tolerada pela convenção, exibindo todo atrito imposto pelas formas hierarquizantes nas relações identitárias e espetacularizadas (Damo, 2007) vincadas entre ídolos e torcedores, los dedos de Dios impôs nova continuidade por intermédio de um ato de diferença.

Da violência às regras esportivas, que bem serviu aos propósitos da política nacionalista, agora o ídolo Maradona, desagregando seus próprios constructos, ${ }^{24}$ reposicionava sua pessoa na condição de ex-jogador dentro da escala torcedora não mais como um ídolo (individual) a resolver um jogo e mudar o destino esportivo da nação, mas como seccionalidade fractal de um contínuo maior (ainda a nação), ao se colocar como um torcedor nacional genérico, ou melhor, um notório (great), porém simples, torcedor popular a exibir os dedos aos adversários naquela sociabilidade contendora.

Nesse sentido, a politização dos gestos de Maradona não deixou de evocar a nacionalidade e, por consequência, alguma identidade nacional, mas o fez diferenciando e abduzindo as representações mais seguras em torno de sua pessoa pública e de seu nome inscrito no panteão dos ídolos nacionais de seu país.

Por fim, arriscaria dizer que antijogo guarda em relação a jogo uma distância qualitativa ou diferenciante, ou seja, não necessariamente é preciso partir de alguma noção de jogo para se alcançar por contraste o antijogo e seus efeitos sobre as relações. Não seria o caso de se presumir que a categoria antijogo esteja contida numa espécie de ontologia em torno de si, mas os efeitos que ela gera não necessariamente cumprem o repertório de caminhos ou linhas (Ingold, 2016) que as noções correntes de jogo sugerem, embora nesse caso teria que coligi-la a cada definição de jogo que se apresentasse, todavia não foi esse

24 Reitero a advertência da autora: "Talvez devêssemos buscar uma apreensão holística da maneira pela qual nossos sujeitos de pesquisa desagregam seus próprios construtos" (Strathern, 2014, p. 242). 
o recorte do artigo. Algumas atitudes antijogo exprimem a diferença dentro de novas retotalizações (iterações do gesto êmico), e parece que os exemplos aqui trazidos, sobretudo o de Maradona, conformariam esse caso. Já outras, digamos, se perderiam na diferença, abduzidas pela sensualidade da diferença, tal como compreendida a partir de Tarde, e aqui poderíamos prospectar antijogo no interior da miríade de comportamentos transgressores torcedores, tema de difícil análise quando alocado somente das perspectivas que tomam por base noções como jogo (Huizinga, Callois, Elias, Simmel, entre outros mais). Aberturas para uma nova extensão das noções de jogo podem passar pelas condutas antijogo e, não obstante, parece que não há muros a constranger essa categoria que acaba fluindo caminhos conceituais próprios que poderão sempre ser colocados à prova etnográfica.

\section{Referências}

ALFONSI, D. Réplicas originais: um estudo sobre futebol nos museus. 2018. Tese (Doutorado em Antropologia Social) - Faculdade de Filosofia, Letras e Ciências Humanas, Universidade de São Paulo, São Paulo, 2018.

ARCHETTI, E. Masculinidades: fútbol, tango y polo em a Argentina. Buenos Aires: Antropofagia, 2003.

BATESON, G. Contraste etológico, competição e cismogênese. In: BATESON, G. Naven: um exame dos problemas sugeridos por um retrato compósito da cultura de uma tribo da Nova Guiné, desenhado a partir de três perspectivas. São Paulo: Edusp, 2008. p. 219-239.

BRITO, S.; MORAIS, J. V. de; BARRETO, T. V. Regras de jogo versus regras morais: para uma teoria sociológica do fair play. Revista Brasileira de Ciências Sociais, v. 26, n. 75, p. 133-146, 2011.

CALLOIS, R. Los juegos y los hombres. México: Fondo de Cultura Económica, 1994.

DAMO, A. Do dom à profissão: a formação de futebolistas no Brasil e na França. São Paulo: Hucitec: Anpocs, 2007.

DEDO do meio, dança e alívio. Maradona vira protagonista em jogo argentino. BOL, 26 jun. 2018. Disponível em: https://www.bol.uol.com.br/copa-2018/noticias/2018/06/26/maradona-e-flagrado-dancando-com-nigeriana-antes-de-jogo-da-argentina.htm. Acesso em: 22 fev. 2019. 
LOS DEDOS de dios. O Antagonista, 29 jun. 2018. Disponível em: https://www.oantagonista.com/o-antagonista-na-copa/los-dedos-de-dios/. Acesso em: 22 fev. 2019.

DELEUZE, G. Différence et répéticion. Paris: Press Universitaires de France, 1972.

DULLEY, I. Roy Wagner e a fractalidade. Considerações sobre o gesto êmico. Campos, v. 15, n. 1, p. 11-36, 2014.

ELIAS, N. Game models. In: ELIAS, N. What is sociology?. New York: Columbia University Press, 1978. p. 71-103.

ELIAS, N. A sociedade dos indivíduos. Rio de Janeiro: Jorge Zahar, 1993.

ELIAS, N.; DUNNING, E. Em busca da excitação. Lisboa: Difel, 1992.

FLORENZANO, J. P. Edmundo e Afonsinho: a rebeldia no futebol brasileiro. São Paulo: Musa, 1998.

FORTUNA, C. Simmel: a estética e a cidade. Coimbra: Imprensa da Universidade de Coimbra, 2011.

GARRIGOU, A. O grande jogo da sociedade. In: GARRIGOU, A.; LACROIX, B. (org.). Norbert Elias: a política e a história. São Paulo: Perspectiva, 1997. p. 65-88.

GASTALDO, E. "O complô da torcida": futebol e performance masculina em bares. Horizontes Antropológicos, Porto Alegre, ano 11, n. 24, p. 107-123, jul./dez. 2005. Disponível em: http://www.scielo.br/scielo.php?script=sci_arttext\&pi d=S0104-71832005000200006. Acesso em: 2 jul. 2019.

GASTALDO, E. As relações jocosas futebolísticas: futebol, sociabilidade e conflito no Brasil. Mana, Rio de Janeiro, v. 16, n. 2, p. 311-325, 2010.

GAY, P. Domínio incerto. In: GAY, P. O cultivo do ódio: a experiência burguesa da rainha Vitória a Freud. São Paulo: Companhia das Letras, 2001. p. 426-428.

GEISER, A; VELHO, O. A liminaridade antropofágica de Roberto DaMatta ou Tupi or not tupi? A virtude está no meio. In: GOMES, L.; BARBOSA, L.; DRUMMOND, J. A. (org.). O Brasil não é para principiantes. Rio de Janeiro: Editora FGV, 2000. p. 67-83.

GONÇALVES, M. Traduzir o outro: etnografia e semelhança. Rio de Janeiro: 7Letras, 2009.

GUEDES, S. Malandros, caxias e estrangeiros no futebol: de heróis e anti-heróis. In: GOMES, L.; BARBOSA, L.; DRUMMOND, J. A. (org.). O Brasil não é para principiantes. Rio de Janeiro: Editora FGV, 2000. p. 125-142.

HUIZINGA, J. Homo ludens. São Paulo: Perspectiva, 1993.

INGOLD, T. Lines: a brief history. London: Routledge, 2016. 
LEIRIS, M. Espelho da tauromaquia. São Paulo: Cosac Naify, 2001.

MAUSS, M. Parentescos de gracejo. In: MAUSS, M. Ensaios de sociologia. São Paulo: Perspectiva, 2001. p. 457-468.

MAUSS, M. Sociologia e antropologia. São Paulo: Cosac Naify, 2003.

RADCLIFFE-BROWN, A. O parentesco por brincadeira. In: RADCLIFFE-BROWN, A. Estrutura e função na sociedade primitiva. Petrópolis: Vozes, 2013a. p. 85-97.

RADCLIFFE-BROWN, A. Notas adicionais sobre os parentescos por brincadeira. In: RADCLIFFE-BROWN, A. Estrutura e função na sociedade primitiva. Petrópolis: Vozes, 2013b. p. 98-107.

SIMMEL, G. Questões fundamentais de sociologia. Rio de Janeiro: Zahar, 2006.

STRATHERN, M. Pontos em expansão. Uma conversa com Marilyn Strathern. Cadernos de Campo, ano 21, n. 21, p. 199-209, 2012.

STRATHERN, M. O efeito etnográfico. São Paulo: Cosac Naify, 2014.

TARDE, G. Monadologia e sociologia. Petrópolis: Vozes, 2003.

THEMUDO, T. Gabriel Tarde: sociologia e subjetividade. Rio de Janeiro: Relume Dumará, 2002.

TOLEDO, L. H. Futebol e teoria social: aspectos da produção científica brasileira (1982-2022). Revista Brasileira de Informações Bibliográficas em Ciências Sociais, n. 52, p. 133-165, 2001.

TOLEDO, L. H. Lógicas no futebol. São Paulo: Hucitec: Fapesp, 2002.

TOLEDO, L. H. Jogo livre: analogias em torno das 17 regras do futebol. Horizontes Antropológicos, Porto Alegre, ano 14, n. 30, p. 191-219, 2008.

TOLEDO, L. H. Presente etnográfico e "presente museográfico": o caso do Museu do Futebol visto por um antropólogo urbano. Cadernos de Campo, v. 28, n. 1, p. 251-272, 2019.

VEBLEN, T. A teoria da classe ociosa. In: VEBLEN. São Paulo: Abril, 1974. p. 277-456. (Coleção Os Pensadores).

VIGARELLO, G.; HOLT, R. O corpo trabalhado - ginastas e esportistas no século XIX. In: CORBIN, A.; COURTINE, J.-J.; VIGARELLO, G. (org.). História do corpo: volume 2. Petrópolis: Vozes, 2005. p. 393-478.

WAGNER, R. A invenção da cultura. São Paulo: Cosac Naify, 2010.

WAGNER, R. A pessoa fractal. Tradução de Christiano Key Tambascia e Iracema Dulley. Ponto Urbe, n. 8, p. 1-14, 2011. 
WAGNER, R. Símbolos que representam a si mesmos. São Paulo: Editora da Unesp, 2017. WAIZBORT, L. As aventuras de Georg Simmel. São Paulo: Editora 34, 2013.

WALDMAN, B.; VOGT, C. A pose, a cópia, o cafajeste. VOGT, C. et al. (org.). Caminhos cruzados: linguagem, antropologia, ciências naturais. São Paulo: Brasiliense, 1982. p. 89-97.

Recebido: 06/03/2019 Aceito: 24/06/2019 | Received:3/6/2019 Accepted:6/24/2019 